\title{
The Effect of a Peer and Self-Assessment-Based Editorial Study on Students' Ability to Follow Spelling Rules and Use Punctuation Marks Correctly
}

\author{
Ömer Faruk Tavşanlı * \\ Elementary School Teaching Department, Istanbul Aydin University, Istanbul, Turkey \\ ORCID: 0000-0003-1366-1679
}

Ülkü Eda Kara

Elementary School Teaching Department, Istanbul Aydin University, Istanbul, Turkey

ORCID: 0000-0002-7681-0128

\begin{tabular}{l}
\hline \hline Article history \\
\hline Received: \\
16.09 .2020 \\
Received in revised form: \\
25.11 .2020 \\
Accepted: \\
13.01 .2021 \\
Key words: \\
\hline Peer assessment, Self \\
assessment, Writing instruction, \\
Spelling rules and punctuation \\
marks
\end{tabular}

In studies conducted to improve primary school students' writing skills, it has been determined that they make errors in the use of the punctuation marks and do not use spelling rules correctly. The purpose of this study was to reveal the effect of a qualified and planned peer and selfassessment-based editorial study [PSABES] on the success of fourthgrade elementary school students in following spelling rules and using punctuation correctly. In this study, an explanatory mixed design was used, and the research was carried out with 60 fourth-grade students attending a public school in Istanbul during the 2019-2020 academic year. According to the results of the research, it was determined that PSABES was effective in students' performance in adhering to spelling rules and using punctuation correctly. This was due to PSABES' contribution to creating a positive attitude toward writing, increasing motivation, learning desire and communication skills, and allowing students to gain a culture of criticism, feel more valuable, recognize their mistakes, take responsibility and write more carefully. This research clearly demonstrates the effects of peer and self-assessment on the correct use of spelling rules, and punctuation marks. In subsequent research, the effects of self and peer assessment on students' overall writing success can be examined, and it can also be investigated how this process plays a role in shaping the writer identity of students.

\section{Introduction}

Writing, which is a tool for thinking, combines what passes through the mind of an individual with certain symbols and rules (Akyol, 2006). Students use writing in all learning areas, and writing is known to affect academic performance in all lessons. Writing affects young children's reading comprehension and literacy skills, playing a major role in their overall academic success. For this reason, writing skills constitute one of the most important skills that should be developed from the preschool period (Hardman \& Bell, 2019). Writing

\footnotetext{
* Correspondency: omerfaruktavsanli@gmail.com
} 
skills are defined as an individual's efficacy in self-expression, ability to communicate in social life, and capacity for academic success at a later age (Tavşanl1, 2019). In addition, it is known that cognitive development, creative and critical thinking, research and problem solving skills, phonological awareness, recognition of words, reading comprehension, and using language operate at a higher level in individuals that have good writing skills (Aram 2005; Bloodgood, 1999; Shatil, Share \& Levin, 2000). Because in the writing process, many cognitive skills come into play in a collaborative fashion. These processes usually require high-level thinking and skills to apply thoughts. In turn, this enables the development of many mental skills.

\section{Writing instruction and process-based writing}

Writing instruction is the product of a mental process that has changed over time to a structure that cares about the process, rather than the product (Lee, 2020). Accordingly, in this process, it is necessary for students to receive feedback before, during and after writing. During the writing process, it is important for the students to offer their opinions about their writings, receive feedback from teachers and their friends, and be encouraged to review and re-write their work in order to improve their writing skills (Patchan, Schunn \& Correnti, 2016).

The majority of students tend to find writing activities boring and difficult because writing is the hardest skill to acquire and develop (Tavşanl1, 2018). Since writing involves the three basic mental processes of planning, drafting and reviewing, these tasks that need to be performed in these processes challenge students cognitively. In reviewing, which is the last stage of the process, it is necessary for students to read their work, find errors, and evaluate the whole text. Then, the text is rewritten in response to the outcome of the review (Schuldt, 2019).

In process-based writing instruction, there are five stages that highlight the process, namely pre-writing, drafting, revising, editing, and publishing (Graham \& Harris, 2017). In the prewriting, the subject to be written is decided, research is done about the writing subject, and the paper's plan is drawn. In the draft stage, the first version of the paper is presented. In the revising part, the paper is examined both contextually and formally. In the editing, the detected errors and deficiencies are corrected, and the writing is rewritten. In the sharing part, it is ensured that the papers meet with a specific audience. These steps must be performed in order to establish an effective outcome in the form of a writing. In particular, the revising, feedback and editing stages are of great importance in increasing writing success (Vattoy, Gamlem \& Rogne, 2020).

\section{Revision and editing in writing}

Revision and editing are considered as the most important stage of the process-based writing approach and many writing learning theories (Schuldt, 2019). This stage starts with the re-reading of the texts the student has written, and in this process, the writer will receive the opinions of their teachers and friends. The formal mistakes made by the students in their writing are determined at this stage and corrected by peers. After revision, the editing phase begins, in which the text is assessed in terms of content and form (Smith, 2003). During the

revision and feedback stages, the text is read again, and the content is edited. After editing the content, the text is re-examined and formal errors are corrected (Graham \& Harris, 2017). With the feedback received from teachers and friends about their writings, students can observe the formal mistakes they made (Koenig, Eckert \& Hier, 2016). In addition, students 
become aware of their writing competence by realizing how they can improve themselves as a result of this feedback (Hier \& Eckert, 2014). The draft and final versions of the text written are important for the development of students' written expression skills (Koenig, Eckert \& Hier, 2016). In fact, the production of these two is the main factor in improving students' writing skills (Graham \& Harris, 2017).

Students are required to talk about their own writing, share their ideas with their friends, revise and edit their writings by engaging in self-assessment and peer reviews (Tavşanlı \& Kaldırım, 2018). The frequent and diverse feedback students receive during the revision step is effective in editing the content, applying spelling rules, and using the punctuation correctly (Hardman \& Bell, 2019). The feedback given to students in writing studies should be of quality that is far from judgement increasing the success of writing (Guenette, 2007). When giving feedback, not only the points in which the student seems inadequate in their writing, but also the good and successful aspects should be discussed (Duijnhouwer, Prins \& Stokking, 2012). All these processes are very important for the development of students' writing skills. At this point, it should not be forgotten that a qualified writing instruction is an achievement that will affect the student's entire future academic and professional life.

Furthermore, it is very important that the students assess their own work and give feedback to their friends about their writing. Therefore, in this research, the PSABES instructional program was conducted to assess how the students improve their own writing skills and those of their friends. In this way, it is aimed that the students' writing will be improved by receiving feedback during the revision and editing phase in the instructional program.

\section{Justification of the study}

When studies on writing skills are examined, it is seen that writing is considered and evaluated as a whole (Graham \& Harris, 2017; Hardman \& Bell, 2019). In activities organized for students to experience and improve their writing skills, dimensions, such as topic selection, researching about a topic, planning of writing, draft writing work, correct use of punctuation marks, performing spelling rules, sentence creation, word selection, fluency, organization, and subject integrity are taken into consideration together (Tavşanl1, 2018). One of these dimensions is the use of spelling rules and punctuation correctly when writing. These rules should not only be known theoretically but also correctly applied by students (Batur et al., 2016). That is to say writing entails the declarative as well as procedural knowledge of these rules. In studies conducted to improve the writing skills of primary school students, it has been determined that they make errors in the use of the punctuation marks and do not use spelling rules correctly (Bağc1, 2007; Batur et al., 2016; Erdem, 2007; Ergin, 2009; Kula, Budak \& Tasdemir, 2015; Y1ldı, 2002). For example, punctuation marks are not considered as part of writing, attention is not paid to their place of use, they are incompletely or excessively used, spelling rules are ignored, and more attention is given to the content of writing (Batur et al. 2016). Hence, in this study, the impact of PSABES on preventing these errors was evaluated.

To improve writing skills, each dimension needs to be addressed; however, an examination of the studies conducted in this area shows that only a few studies handle these dimensions individually (Duijnhouwer, Prins \& Stokking, 2012; Truckenmiller et al., 2014). In addition, there is nonspecific activities designed for teachers to present the correct use of spelling rules and punctuation. It is considered that PSABES will also be beneficial in addressing this deficiency. At this point, the effect of the research on this shortcoming is also a matter of 
curiosity.

In this context, the purpose of the study was to reveal the effect of a qualified and planned PSABES that supports following the correct spelling rules and effectively using punctuation marks to develop the successful writing of fourth-grade elementary school students. To achieve this goal, an answer to the following research question was sought:

- Does PSABES have an impact on elementary school students' success in following the spelling rules and being able to correctly use punctuation marks?

\section{Method}

\section{Research design}

A mixed methodology, in which quantitative and qualitative research methods were used together (Tashakkori \& Teddlie, 2003), was chosen for the collection, analysis and interpretation of the data obtained in this study. In this type of research, quantitative and qualitative research approaches are used together to understand the purpose, problem and solution of the research, analyze and interpret the findings in depth (Johnson, Onwuegbuzie \& Turner 2007).

In this study, an explanatory mixed design was used. From time to time, researchers should consider the research in depth with additional information when conducting quantitative research. Such situations are generally based on explaining the reason for the quantitative research results. For this purpose, it is aimed to explain the quantitative results in detail and regularly by adding a qualitative section (Fraenkel, Wallen \& Hyun, 2011). This design was selected for the current research because a single method was not sufficient for the research situation. This is because the effect of an independent variable (PSABES) on a dependent variable (spelling rules and success in using punctuation marks) was examined, and in investigating this effect the aim was to include the qualitative dimension in the process and evaluate the quantitative results in more depth. Thus, more accurate and holistic results were achieved in the research. The visual view of the research design is given in Figure 1 (Fraenkel, Wallen \& Hyun, 2011).

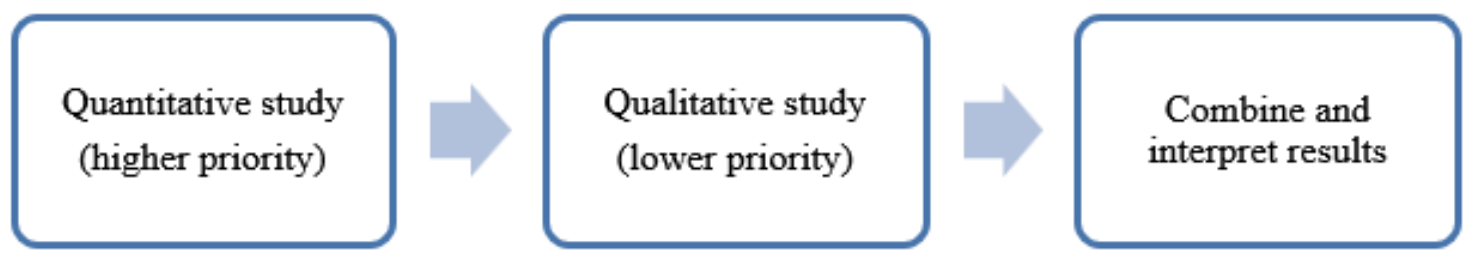

Figure 1. Symbolic view of the research design

In the quantitative dimension of the research, a pretest-posttest control group design as one of the quasi-experimental research methods was chosen. In quasi-experimental studies, participants are not assigned to groups randomly (Creswell, 2012). In the quasi-experimental design, the researcher first conducts a pretest; then, the instruction process is undertaken in the experimental group. In this study, the control group undertook writing activities within the scope of the Turkish curriculum (Ministry of National Education [MoNE], 2015). These courses in the control group provided students with process-based writing training. However, there was no instruction about how to make revisions and corrections as is the case with the 
experimental group. Then, the researcher conducted a posttest with the experimental and control group. Finally, the researcher evaluated the differences between the groups (Creswell, 2012; Fraenkel, Wallen \& Hyun, 2011). In the quantitative part of the study, the students' use of spelling rules and punctuation marks were examined.

In the qualitative dimension of the study, a case study design was used. The main feature of a case study is an in-depth analysis of one or more events. Factors related to a situation (environment, individuals, events, processes, and alike) are investigated with a holistic approach which aims to reveal how they affect and are affected by the situation (Creswell, 2012). In the qualitative part of the study, the students' and the teacher views on PSABES were discussed.

\section{Study group}

The research was carried out with 60 fourth-grade students attending a public school in Istanbul in the 2019-2020 academic year. The participants were selected using the convenience sampling technique, which is a type of nonprobability sampling in which people are sampled simply because they are "convenient" sources of data for researchers (Creswell \& Clark, 2018). The volunteering principle was taken into consideration in the selection of the school. The two classes, which were included in the research, were determined according to an achievement test. The overall test level of each of these classes was equal; therefore, one class was assigned as the experimental group and the other as the control group. There were 30 students in both classes; the experimental group consisted of 11 male and 19 female students and the control group contained 14 male and 16 female students. In the qualitative part of the research, interviews were conducted with six students and one teacher who undertook the instruction in the experimental group. Some criteria were taken into consideration during the selection of students in the qualitative part of the research. The first criterion was pertinent to the fact that whether the students' level was good, moderate or inadequate according to their scores in their writing. In addition to the students' writing scores, their success in the Turkish language course and teacher opinions were also examined and attention was paid to ensure that these results were parallel to each other. The last criterion was the choice of students' higher-level speaking skills in Turkish to obtain more data in the interviews. The findings were supported by the one-to-one discourses of students which were given a code label in accordance with the ethical rules of the Turkish Council of Higher Education [CoHE].

Within the scope of PSABES implemented in the experimental group, the process of revision and editing was emphasized, which allowed the participants to detect errors in the writings. Then, the students were given the opportunity to improve the clarity of their writings and share them again. Thus, the students rewrote their texts according to the feedback. In the control group, the writing was based on topics in the Turkish course curriculum. The only difference between the experimental and control groups was that more emphasis was placed on the revision and editing stages in the former.

\section{Instructional process}

Before the PSABES started to be implemented, teacher training was carried out. The teachers of both the experimental and the control groups were trained together and the program they were going to apply was introduced in detail. In order to minimize teacher influence, the importance of teaching only in line with the given instructions was emphasized. When implementation started, different types of text writing trials were carried out during the 
lesson hours, referred to as 'writing workshops' with the students in the experimental group. The process consisted of selecting a writing topic and developing it, drafting, revising, giving feedback, editing, and sharing. During the revision and editing phase, the students sometimes shared their writing with all their classmates and received feedback. In this process, evaluation forms were used, consisting of two separate forms: one to evaluate the student's own writing and the other to evaluate their classmates' writing. In each writing activity, the students examined their own writing and the writing of a classmate according to the evaluation form. In addition, students presented the spelling and punctuation errors on paper. In this stage, while the teacher directed the process, s/he discussed the students' writing. In the final stage, the students completed their writing and shared it with the editors who made their final evaluations about the quality of the writings. The students corrected their own writings for the last time according to the evaluations. The aim was for students to develop their writing skills in both content and form. Along with revision and editing, the errors in the use of punctuation marks during the writing process and overlooked spelling rules were revealed and corrected. The control group shared the texts they wrote with their classmates and teacher but did not receive systematic feedback.

\section{Data Collection Process}

The duration of the instructional process was 10 weeks. The writing study was implemented for two hours each week. A total of 240 texts of four different types were written by students in the experimental and control groups. Of these writings, 120 were created by the students in the experimental group according to PSABES. The members of the control group also wrote four texts each based on the Turkish course curriculum. The first and last samples written by the students in both groups were accepted as the pretest and posttest.

Semi-structured interview forms developed by the researchers for the purpose of the study were used to collect the qualitative data of the research. An average of 15 minutes of interviews were undertaken with the teacher and students in the experimental group, and their opinions about PSABES were obtained. These interviews were recorded with a voice recorder and transcribed. In this process, a total of 87 minutes of recordings were made, and 11 pages of written documents were obtained by extracting the records. The transcripts obtained were shared once again with the participants and checked whether what they said had been transcribed correctly. After this stage, both the audio recordings, the raw form of the data, and their written forms were sent to an external researcher. The researcher determined the compatibility of written records and written documents, and confirmation was obtained that the sound recordings were transferred completely and error-free.

\section{Data Analysis}

In this research, the 6+1 Trait Writing Model (Smith, 2003) was used to evaluate the students' writings. According to this model, the texts were evaluated using the rating key (1-35 points) in the spelling field (punctuation and spelling rules). Then, the success of using punctuation marks and spelling rules in the first and last writing of the students were examined. Evaluation was undertaken by two different researchers, and the consistency was checked. The consistency between the evaluation points of the researchers ( $r s=.95 ; \mathrm{p}<.01$ ) was found sufficient for reliability. The Shapiro-Wilk normality test was used to determine whether the scores of the groups showed normal distribution. In the comparison of the pretest and posttest scores obtained from the groups, the t-test was used.

For the analysis of the qualitative dimension of the research, the responses given by the 
teacher and students in the experimental group to the questions in the interview form were used. In this study, the content analysis method was applied to understand the meaning of the teacher and students' discourse about peer and self-assessment-based editorial study, the context in which the meaning is formed, and the experiences of feedback that constitute an essential step of the writing skill (Merriam, 1998). This method has also been used to reveal the underlying relationships of students' and teachers' discourse on peer and self-assessmentbased editorial study. According to the content analysis method used in data analysis, students' and teachers' discourses were first coded. After coding, themes were determined according to the codes, and each code was classified under the relevant theme.

\section{Findings}

In this section, the quantitative and qualitative findings are presented separately.

To examine the effect of PSABES on students' following spelling rules and using punctuation marks correctly, firstly, the normality of the data was checked. The Kolmogorov-Smirnov normality test showed that the data were distributed normally $(\mathrm{p}>0.05)$. In addition, the skewness and kurtosis coefficients of the data were between -1 and +1 , which supported the normal distribution of the data. Thus, since the data was normally distributed, an independent samples t-test was conducted for the pretest and posttest. The pretest results are shown in Table 1.

Table 1. Pretest Results of the Experimental and Control Groups

\begin{tabular}{lcccccc}
\hline Groups & $\mathrm{N}$ & $\mathrm{X}$ & $\mathrm{SS}$ & $\mathrm{Sd}$ & $\mathrm{t}$ & $\mathrm{p}$ \\
\hline Control & 30 & 2,53 & 1,13 & & & \\
Experimental & 30 & 2,80 & 2,21 & 58 &, 878 &, 384 \\
\hline$* \mathrm{p}<.05$ & & & & & &
\end{tabular}

According to these results, there was no significant difference between the experimental and control groups in terms of their success in following the spelling rules and using punctuation marks correctly $(\mathrm{t}(2-53)=.384 ; \mathrm{p}>.05)$. The posttest results are shown in Table 2 .

Table 2. Posttest Results of the Experimental and Control Groups

\begin{tabular}{lcccccc}
\hline Groups & $\mathrm{N}$ & $\mathrm{X}$ & $\mathrm{SS}$ & $\mathrm{Sd}$ & $\mathrm{t}$ & $\mathrm{p}$ \\
\hline Control & 30 & 2,73 & 1,36 & \multirow{2}{*}{58} & 3,167 & \multirow{2}{*}{$002^{*}$} \\
Experimental & 30 & 3,80 & 2,24 & & & \\
\hline
\end{tabular}

$* p<.05$

The posttest results revealed a significant difference between the experimental and control groups in terms of success in following the spelling rules and using punctuation marks correctly $(\mathrm{t}(2-53)=.002 ; \mathrm{p}<.05)$. This significant difference was in favor of the experimental group.

The findings including the pretest-posttest results of the experimental group are presented in Table 3. A paired samples t-test was conducted for the pretest-posttest difference of the experimental group. 
Table 3. Pretest and Posttest Results of the Experimental Group

\begin{tabular}{lcccccc}
\hline Tests & N & X & SS & Sd & t & p \\
\hline Pretest & 30 & 2,80 & 1,21 & \multirow{2}{*}{29} & $-4,349$ &, $000^{*}$ \\
Posttest & 30 & 3,80 & 1,24 & & &
\end{tabular}

$* \mathrm{p}<.05$

Table 3 shows that there was a significant difference between the mean scores of the students in the experimental group for the first and last writing samples [t $(29)=-4.349 p<.05]$. PSABES conducted with students in the experimental group had influenced their success in following the spelling rules and using punctuation correctly. The findings including the pretest-posttest results of the control group are presented in Table

Table 4. Pretest and Posttest Results of the Control Group

\begin{tabular}{lcccccc}
\hline Tests & N & X & SS & Sd & t & p \\
\hline Pretest & 30 & 2,53 & 1,13 & & & \\
Posttest & 30 & 2,73 & 1,36 & 29 &,- 902 &, 375
\end{tabular}

$* \mathrm{p}<.05$

According to Table 4, no significant difference was found between the average scores of the students in the control group for the first and last writing samples [t $(29)=-.902 \mathrm{p}>.05$ ] Writing studies conducted with the students in the control group did not affect their success in following the spelling rules and using punctuation correctly.

In this section, the opinions of the students in the experimental group and their teacher about PSABES are presented. The data show that the opinions were grouped under four themes as affective dimension, culture of criticism, communication, and awareness about self-writing.

First, the discourses containing positive and negative attitudes under the theme of affective dimension are notable. The students who had positive attitudes toward PSABES stated that this study was fun and improved their writing. Having fun during PSABES and participating in activities willingly was one of the important factors for their success in following spelling rules and using punctuation marks correctly. The students who had negative attitudes toward the study emphasized their anxiety in being criticized, and some students were not able to overcome their fear of criticism. In this context, further studies are needed in which students can realize the value of constructive criticism. Below are two examples of different student responses:

Student 1: Yes. I like it very much because it was a very nice event. I also think I had fun and improved my writing (positive attitudes).

Student 2: I felt strange. I did not like seeing my mistakes. It made me feel bad. I was very upset at first (negative attitudes).

The teacher stated that PSABES increased the students' positive attitudes toward writing, and that students who did not enjoy writing previously began to like it after PSABES. At this point, it is noteworthy that the discourse of the students who stated that they liked PSABES was similar to that of the teacher. A further finding was that the students with a previously negative attitude tended to change their attitude toward writing after PSABES. This was observed by the teacher in the following manner: 
Teacher: Some students who were dissatisfied with the writing process became more willing to write because they liked this stage. They liked to criticize. In this stage, I observed that the students who had a negative attitude toward writing changed their mind and felt more positive.

In addition, it was observed that the students expressed excitement toward this study, stating that it was a pleasure to correct their writing and read it to their classmates. This finding shows that at the end of PSABES, the students were more willing to share their writings with their friends. For example:

Student 5: Of course. I was excited because I wanted to correct my writing as soon as possible and read it to you and my classmates. I corrected my mistakes immediately. I was happy when my writing was appreciated.

Under this theme, however, some students said that they were angry due to unfair criticism. One reason for this was that the student said that their writing was correct, but their friends made mistakes while checking the text. An example of this situation is presented below.

Student 5: My friends were occasionally correcting my writing incorrectly. My classmates sometimes tried to fix errors, but they did not know how to do it, and their correction was actually wrong. I got angry at this.

Under this theme, the teacher had a different perspective from some of the students, such as PSABES' increasing the motivation of the students, enabling them to value themselves more, and, increasing their willingness to teach and their efforts to reduce their mistakes. Furthermore, students' high motivation, feeling more valuable, being more willing to teach and efforts to reduce their mistakes will have positive effects on their writing success. Four examples of the teacher's discourse are as follows:

Students already love the process of writing, and when criticism is added to this process, they better adapt (provide motivation).

In the process, revision and editing the writing of classmates like an editor made them feel valuable. The stage of being an editor was perhaps the most enjoyable process because they were correcting their classmates' writings with the knowledge they had acquired (feeling more valuable).

Students' willingness to learn has increased because at the revision and editing stage, the students first re-learned these rules and repeated them. They noticed the errors in the writing and corrected them because they did not want to receive negative criticism (willingness to learn).

They were trying not to make mistakes and find the mistakes they had made. Of course, to do this, they had to know the spelling rules and punctuation well (efforts to reduce their mistakes).

Another theme that the students and their teacher expressed concerned over was the culture of criticism. Under this heading, the students stated being open to criticism, closed to criticism, and gaining pleasure while criticizing someone's writing. Students who were open to criticism said that they made less mistakes in their writing, and thus were happy that their writing was criticized. This response potentially confirms that as a result of PSABES, the students made 
fewer mistakes. The students that were closed to criticism stated that they wanted to find their own mistakes, not have them discovered by their classmates; however, they explained that even if this upset them, their writing got better. Thus, these comments can be seen in the discourses of two students with different attitudes to criticism by peers:

Student 3: I'm very happy to find my mistakes. Why? Because I love fixing my mistakes. I was also happy when reading my articles (being open to criticism).

Student 4: I didn't like it a bit because I made mistakes, but it was still useful. I was a bit upset when I read what my friends wrote on colored post the notes because they always wrote bad things about my work (being closed to criticism).

In this context, the teacher stated that due to PSABES, the students gained critical thinking skills. However, in this process, some students did not like the evaluation of their writing and stated that they did not want to be criticized in this way and they were those who made more mistakes in their writing. To overcome this feeling, it is important that the students understand the process of feedback in education. Students' perception of feedback as humiliation and dissatisfaction with this process is one of the obstacles in the development of their writing. Two of the responses of the teacher were:

The students argued and revealed the correct aspects of their writing. The teacher provided guidance. Multiple opinions about the texts were stated. In this sense, I also presented the students with a critical thinking approach (being open to criticism).

Only a few students that made a lot of mistakes in their writing did not like this process. They also wanted to work as editors but did not want their writing to be evaluated. The students who did not like being criticized negatively were upset during this process (being closed to criticism).

On the other hand, some students stated that they enjoyed finding mistakes and criticizing their friends' writing. At the same time, these students said that they liked to give advice. This situation shows that the students were able to internalize and implement PSABES effectively. For example:

Student 6: I loved finding my classmates' mistakes. I really liked to criticize their writings. It is also very fun to give advice; for example, 'you can write like this'. Of course, they were sometimes angry with me.

One of the themes obtained from the comments of the teacher and students was the communication dimension of PSABES, within which the students focused on the benefits of sharing what they knew. The teacher stated that this interactive process resulted in students' taking more responsibility and emphasized that sharing knowledge gave students a sense of responsibility. These discourses reveal that both teacher and students prioritized the interactive aspect of PSABES. The students' communication with each other during the process of giving feedback and transferring what they knew placed them in a more intelligent position. This enabled the students to increase their success by helping their peers, which is shown in the comments of a student and teacher:

Student 2: Yes, I think it is definitely very useful. I have corrected both my own and my friends' writing. It was very good to show my mistakes to my classmates. They showed theirs to me, and our writing got better. 
Teacher: Transferring what they learned to their friends enabled them to take responsibility for following and paying more attention to the rules.

The last theme obtained from the opinions of students and teacher concerns the awareness about their writings. First, in developing this awareness their writing skills developed. Realizing that students' writing skills improved with PSABES could make peer feedback a part of their life. This enables students not only to improve their writing skills, but also to be more successful in many areas. One student expressed their writing got better as a result of PSABES in the following way:

Student 2: Yes, I benefited from this study. I developed my writing. I wrote faster and I started writing better. I also did not use spaces before, but now I do.

The teacher who implemented PSABES stated that the students' writing was better. This view reveals that the teacher and students agreed that PSABES improved their writing skills. The students who realized that their writing improved reached the point to develop this further. As the teacher commented:

Teacher: My students often stated that they had the opportunity to detect and correct their mistakes more quickly. Especially writing and sharing good paper made them very happy. Now I can say that they write better.

Another discourse expressed under this theme is that students realized their mistakes as a result of this process. Gaining this awareness was an opportunity for the students to write better since it allowed them to perceive and correct their mistakes. One of the most important points in improving their writing was to notice the mistakes made as the example discourses reveal:

Student 2: Yes, I would like to continue this study because this activity tells me about my mistakes. I could write better and more easily.

Teacher: They noticed their errors in the writing and corrected it because they did not want to receive negative criticism.

One of the comments presented under the awareness theme was related to the students paying attention to what they were writing. Carrying out any work more carefully is very important for development, and this increased the student's focusing power, and consequently they made less mistakes. As confirmed by a student and the teacher:

Student 4: I also had to pay more attention to everything. So, my writing is beautiful.

Teacher: Because they (students) both learned and taught, they took the study even more seriously. This allowed them to pay more attention to the formal features of their writings.

One of the discourses expressed under this theme was that PSABES increased students' sense of responsibility. Since the students checked the writing of their classmates, this gave them a serious responsibility, which, in turn, made them further internalize the rules while managing the writing. This is confirmed by the teacher:

Teacher: I can say that students' sense of responsibility increased in the process. They acted more responsibly to check their friends' writings correctly. 
Other points expressed by students under this theme were that when they took their time, they wrote better and did not want to make mistakes because they wanted to be perfect. This shows that students had come to realize that writing was a serious effort and a time-consuming activity. Gaining this awareness allowed them to spend more time on their writing and increased the quality of their writing. This is shown in the two comments below.

Student 1: I wanted to make no mistake. I want my writing to be completely error-free.

Student 6: I write more beautifully now. You can read what I write. I write better; I write without haste. I write better when I take the time.

In addition to these themes, the teacher who implemented the instruction focused on two more points: First, experience increased teaching performance and this study was more productive because s/he had been engaged in writing study beforehand. Thus, the positive effect of the teaching experience in an instructional process could be seen. S/he then stated that the program was well defined, and clear guidelines given in the assessment of each dimension would reduce anxiety. This situation reveals that teachers need correct and clear guidance. The fact that the instruction was well defined and clearly communicated increased the teacher's performance. The teacher explained her experience and how s/he enjoyed the implementation as:

Teacher: I have undertaken writing studies with my students before. In fact, we were particularly working on writing poetry. We were doing story studies from time to time last year. For this reason, it was more productive, and I was more experienced in teaching writing because of the writing studies I had done.

Teacher: I also enjoyed the process more since the stages make it easy for the teacher to plan. Also, knowing that every stage has an evaluation criterion made me very comfortable in the process.

\section{Discussion and Conclusion}

According to the results of the research, PSABES was found to be effective in students' following the spelling rules and using punctuation correctly. Implementing PSABES offered students a positive attitude toward writing, increased their motivation, learning desire and communication skills, and allowed students to gain a culture of criticism, feel more valuable, recognize their mistakes, take responsibility for their work, and write more carefully.

This is a promising result considering that previous research showing that students' success in using spelling rules and punctuation is low (Batur et al, 2016; Ergin, 2009; Y1ld1z, 2002). Furthermore, there are few studies that measure the effect of an activity or approach directly on students' spelling rules and punctuation marks. However, various research has revealed that feedback increases students' fluent writing success (Hier \& Eckert, 2014; Koenig, Eckert \& Hier 2016; Truckenmiller et al., 2014; Kaya et al., 2020). Black and William (1998) stated that feedback was very effective in the learning processes. Feedback has been shown to be more important, especially in studies based on a product, such as writing because the quality of the resulting product depends on the qualified feedback given in this process (Graham \& Harris, 2017). The more appropriate feedback given to the student during the writing process, the more successful their writing will be. In a meta-analysis which examined the effect of feedback on writing success, 16 studies were evaluated, and it was reported that feedback was 
effective in writing success (Graham, Harris \& Hebert, 2011). In particular, giving feedback related to errors in spelling rules and punctuation marks which are commonly made by students improves the quality of their writing. In this respect, the current research supports the results of Kaya et al. (2019), who reported that the frequency of feedback received by fourthgrade students increased their success in writing according to the content, organization, and technical writing rules. Tavşanlı et al. (2020) stated that reviewing is necessary to improve writing by finding spelling errors.

There are also studies concerning the impact of the early contribution of writing-related feedback to student achievement. Jasmine and Weiner (2007) examined the effect of feedback received from teachers and students on the development of first-grade students. It was found that the students followed the feedback they received regarding the content and technical writing rules. This situation was interpreted as the contribution of feedback to the improvement of writing skills, even for the first-year students. Case-Smith, Weaver, and Holland (2014), in a study conducted with one hundred and thirty-eight first-year students, applied a program called Write Start to one group, while the other group received standard handwriting and writing instruction. Write start program was based on feedback, encouraged self-evaluation, and facilitated peer modeling and peer evaluation. According to the study's findings, the fluent writing success of the group that applied the start to write was significantly different from the other group. Philippakos and MacArthur (2016) conducted studies with fourth and fifth-grade students both on to give and receive feedback. In the study in which 145 students participated, the students were divided into three groups. These groups are reviewer, reader control, and time control. It was observed that the reviewers in the study had the highest writing success. Brakel (1990) conducted a study with ninety-three sixth grade students, on the writing processes of one group receiving feedback and those of the other group receiving no feedback. The results were reported as those who wrote with feedback were more successful. According to these studies, writing with feedback increased students' writing success, and these included spelling rules and punctuation marks. This study supports the findings of the study by Brakel (1990), Case-Smith, Weaver, and Holland (2014), Philippakos and MacArthur (2016) and Jasmine and Weiner (2007).

However, there are studies with different findings (Limpo, Alves \& Fidalgo, 2014; Paquette, 2009). In these studies, it was stated that although feedback had an effect, it did not change according to grade levels. Therefore, the current study does not support the results of the studies of Paquette (2009) and Limpo, Alves and Fidalgo (2014, which found that giving feedback and reviewing students' writings at an early age had no effect on their writing. However, in the studies mentioned above, the reason why feedback did not affect students' writing success at a young age can be attributed to the ineffective use of feedback. Therefore, programs should be implemented for early learners to offer the skills that will allow them to evaluate their writing. Success in writing is related to how students review their writings and evaluate their feedback. In this respect, the current study was effective as self and peer assessment was used effectively.

One of the reasons why students' success in using the spelling rules and punctuation marks increase is that feedback was given both orally and in written form. Previous research has revealed that it is more effective for students to give different types of feedback both orally and in written form (Bitchener, Young \& Cameron 2005; Duijnhouwer, Prins \& Stokking 2012).

Another reason why PSABES has an effect on using spelling rules and punctuation marks is 
that it encompasses a positive attitude toward the students' opinions. Research shows that the attitude toward writing has an effect on writing success (Bayat, 2014; Hess \& Wheldall, 1999; Tavşanlı, 2019). Another fact revealed in the research is that PSABES increases students' writing motivation, desire to learn and communication skills. This situation is seen as one of the reasons for the increase in the success of students' using writing rules and punctuation marks correctly because motivation and desire to learn are considered as keys to success (Morrow \& Young, 1997). Similarly, communication skills also make a positive contribution to learning processes as they facilitate instant contact within learning processes (Powell \& Powell, 2015). Considering the writing skills, it is very important for the student to receive feedback immediately and transfer the feedback using the appropriate communication channels (McCarthey, Woodard \& Kang, 2014; Tavşanlı et al., 2020).

Interviews with students and teachers show that the culture of criticism; that is, being open to criticism, also has an impact on students' achievements. Knowing its deficiencies and overcoming these deficiencies are important conditions of success in any field (Jarvis, Holford \& Griffin, 2003). In the current research, the importance of both self-criticism and being criticized by classmates during PSABES was emphasized, and it was made clear to the students that this was an opportunity to improve their writing.

Another reason for the increase in the students' success in using the spelling rules and punctuation marks was that they took responsibility and were more careful in their writing. The students were especially careful when giving feedback to their classmates' writing. Thus, the students became more aware of the rules and their own success increased while carefully analyzing their classmates writing. In this process, the task of making their classmates writing better led them to take responsibility, and they were very meticulous in this process. Taking responsibility in educational processes is an action that increases motivation. The fact that students take responsibility and have a share in their own learning is very effective in permanent learning (Cook-Sather, 2010; Peters, 2015). In addition, being careful is known to be quite effective in success (Loughran, 2013).

The current research is very important in terms of showing how effective peer and selfassessment positively affects students' writing success. With this research, the effects of peer and self-assessment on the correct use of spelling rules and punctuation marks were clearly demonstrated. In this process, a positive attitude toward writing, high motivation and desire to learn were especially emphasized. These factors, which include affective experiences for writing, played a very important role even in the most technical aspect of writing, rules of writing, including those related to spelling and punctuation. Thus, the importance of the affective dimension of learning was emphasized again. The current study should also be taken into consideration in terms of revealing the extent to which feedback affects student success in developing their writing skills. Realizing the mistakes in their writing and the points that need to be improved through feedback, the students not only improved their writing but also realized the importance of accepting criticism.

The current research focused on following spelling rules and correctly using punctuation marks. In subsequent research, the effects of self and peer assessment on students' overall writing success can be examined, and it can also be investigated how this process plays a role in shaping the writer identity of students. 


\section{Note}

This study orally presented at the "Education Research Congress" (FSMVU-EAK2020) held at Fatih Sultan Mehmet University from 26-27 March 2020.

\section{References}

Akyol, H. (2006). Turkish first reading and writing instruction. Pegem A Publishing, Ankara.

Aram, D. (2005). Continuity in children's literacy achievements: A longitudinal perspective from kindergarten to school. First Language, 25, 259-289.

Bağc1, H. (2007). An evaluation of the attitudes of the candidates of teacher of Turkish towards written expression and the courses of written expression. Journal of Turkology Research, 21(21), 29-61.

Batur, Z., Akar, C., Tufan, B. S., \& Topaloğlu, N. (2016). Second grade primary school students' punctuation marks using skill. International Journal of Turkish Education and Training, 1(2), 46-60.

Bayat, N. (2014). The effect of the process writing approach on writing success and anxiety. Educational Sciences: Theory \& Practice, 14(3), 1123-1141.

Bitchener, J., Young, S., \& Cameron, D. (2005). The effect of different types of corrective feedback on ESL student writing. Journal of Second Language Writing, 14, 191-205.

Black, P., \& Wiliam, D. (1998). Assessment and classroom learning. Assessment in Education, 5, 7-74.

Bloodgood, J. W. (1999). What's in a name? Children's name writing and literacy acquisition. Reading Research Quarterly, 34, 342-367.

Brakel, V. L. (1990). The revising processes of sixth-grade writers with and without peer feedback. The Journal of Educational Research, 84(1), 22-29.

Case-Smith, J., Weaver, L., \& Holland, T. (2014). Effects of a classroom-embedded occupational therapist-teacher handwriting program for first-grade students. American Journal of Occupational Therapy, 68(6), 690-698.

Cook-Sather, A. (2010). Students as learners and teachers: Taking responsibility, transforming education, and redefining accountability. Curriculum Inquiry, 40(4), $555-575$.

Creswell, J. (2012). Educational research: Planning, conducting, and evaluating quantitative and qualitative research. Boston: Pearson Publication.

Creswell, J. W., \& Clark, V. L. P. (2018). Designing and conducting mixed methods research. Thousands Oaks, California: Sage publications.

Duijnhouwer, H., Prins, F. J., \& Stokking, K. M. (2012). Feedback providing improvement strategies and reflection on feedback use: Effects on students' writing motivation, process, and performance. Learning and Instruction, 22, 171-184.

Erdem, H. (2007). High school $9^{\text {th }}$ class students' acquisition level of orthography and punctuation rules. Unpublished Master's Thesis, Gazi University, Institute of Educational Sciences, Ankara, Turkey.

Ergin, S. (2009). Primary school 8th grade students' skills of using punctuation. Unpublished Master's Thesis, Gazi University, Institute of Educational Sciences, Ankara, Turkey.

Fraenkel, J., Wallen, N., \& Hyun, H. (2011). How to design and evaluate research in education. New York: Mc Graw Hill Publications.

Graham, S., Harris, K., \& Hebert, M. A. (2011). Informing writing: The benefits of formative assessment. A Carnegie Corporation Time to Act report. Washington, DC: Alliance for Excellent Education. 
Graham, S., \& Harris, K. R. (2017). Evidence-based writing practices: A meta-analysis of existing meta-analyses. In Design principles for teaching effective writing (pp. 13-37). Brill.

Guenette, D. (2007). Is feedback pedagogically correct? Research design issues in studies of feedback on writing. Journal of Second Language Writing, 16, 40-53.

Hardman, W., \& Bell, H. (2019). More fronted adverbials than ever before'. Writing feedback practices and grammatical metalanguage in an English primary school. Language and Education, 33(1), 35-50.

Hess, M., \& Wheldall, K. (1999). Strategies for improving the written expression of primary children with poor writing skills: A sociocognitive perspective. Australian Journal of Learning Difficulties, 4(4), 14-20.

Hier, B. O., \& Eckert, T. L. (2014). Evaluating elementary-aged students' abilities to generalize and maintain fluency gains of a performance feedback writing intervention. School Psychology Quarterly, 29(4), 488-502.

Jasmine, J., \& Weiner, W. (2007). The effects of writing workshop on abilities of first grade students to become confident and independent writers. Early Childhood Education Journal, 35(2), 131-139.

Jarvis, P., Holford, J., \& Griffin, C. (2003). The theory \& practice of learning. Psychology Press.

Johnson, R.B., \& Onwuegbuzie, A.J., \& Turner, L.A. (2007). Toward a definition of mixed methods research. Journal of Mixed Method Research 1(2), 112-133.

Kaya, B., Ateş, S., Yıldırım, K., \& Rasinski, T. (2020). Effect of feedback on Turkish fourthgrade elementary school students' fluent writing skills. Education and Science, 45(201), 189-205.

Koenig, E. A., Eckert, T. L., \& Hier, B. O. (2016). Using performance feedback and goal setting to improve elementary students' writing fluency: A randomized controlled trial. School Psychology Review, 45(3), 275-295.

Kula, S., Budak, Y., \& Taşdemir, M. (2015). The fourth grade students' learning level of the punctuation rules. International Journal of Eurasia Social Sciences, 6(18), 58-80.

Lee, Y. J. (2020). The long-term effect of automated writing evaluation feedback on writing development. English Teaching, 75(1), 67-92.

Limpo, T., Alves, R. A., \& Fidalgo, R. (2014). Children's high-level writing skills: Development of planning and revising and their contribution to writing quality. British Journal of Educational Psychology, 84, 177-193.

Loughran, J. (2013). Developing a pedagogy of teacher education: Understanding teaching \& learning about teaching. Routledge.

McCarthey, S. J., Woodard, R., \& Kang, G. (2014). Elementary teachers negotiating discourses in writing instruction. Written Communication, 31(1), 58-90.

Merriam, S. (1998). Qualitative Research and Case Study Applications in Education. San Francisco: Jossey- Bass.

Ministry of National Education (MoNE). (2015). The elementary school Turkish language arts course (1-8 grades) teaching program and guidance. Ankara, Turkey: Government Books Press.

Morrow, L. M., \& Young, J. (1997). A family literacy program connecting school and home: Effects on attitude, motivation, and literacy achievement. Journal of Educational Psychology, 89(4), 736.

Paquette, K. R. (2009). Integrating the $6+1$ writing traits model with cross-age tutoring: An investigation of elementary students' writing development. Literacy Research and Instruction, 48, 28-38. 
Patchan, M. M., Schunn, C. D., \& Correnti, R. J. (2016). The nature of feedback: How peer feedback features affect students' implementation rate and quality of revisions. Journal of Educational Psychology, 108(8), 1098-1120.

Peters, R. S. (2015). Authority, responsibility and education. Routledge.

Philippakos, Z. A., \& MacArthur, C. A. (2016). The effects of giving feedback on the persuasive writing of fourth-and fifth-grade students. Reading Research Quarterly, 51(4), 419-433.

Powell, R. G., \& Powell, D. L. (2015). Classroom communication and diversity: Enhancing instructional practice. Routledge.

Schuldt, L. C. (2019). Feedback in action: Examining teachers' oral feedback to elementary writers. Teaching and Teacher Education, 83, 64-76.

Shatil, E., Share, D. L., \& Levin, I. (2000). On the contribution of kindergarten spelling to Grade 1 literacy: A longitudinal study in Hebrew. Applied Psycholinguistics, 21, 1-21.

Smith, C. B. (2003). Successful use of the six traits in writing (Rapor No. TBC-03005). ERIC Topical Bibliography and Commentary. (ERIC Document Reproduction Service No. ED481235).

Tashakkori, A., \& Teddlie, C. (2003). Handbook of mixed methods in social \& behavioral research. Thousand Oaks, CA: Sage.

Tavşanlı, Ö. F. (2018). What do primary school students write about?: Investigation of text types, subjects and content preferences in the written works of primary school students. Journal of Mother Tongue Education, 6(1), 32-47.

Tavşanlı, Ö.F., \& Kaldırım, A. (2018). Investigating the opinions of second grade elementary school students on process based writing practices. Journal of Mother Tongue Education, 6(3), 859-876.

Tavşanlı, Ö.F. (2019). The effect of process writing modular program on the attitude towards writing, writing skills and writer identity of the 2nd grade elementary school students'. Unpublished Doctoral Dissertation, Uludag University, Turkey.

Tavşanlı, Ö.F., Yıldırım, K., Bilgin, A., Rasinski, T., \& Tschantz, B. (2020). The Effect of a PBWMIP on Writing Success and Attitude toward Writing. Reading \& Writing Quarterly. DOI: 10.1080/10573569.2020.1846006

Truckenmiller, A. J., Eckert, T. L., Codding, R. S., \& Petscher, Y. (2014). Evaluating the impact of feedback on elementary aged students' fluency growth in written expression: A randomized controlled trial. Journal of School Psychology, 52, 531-548.

Vattoy, K. D., Gamlem, S. D., \& Rogne, W. M. (2020). Examining students' feedback engagement and assessment experiences: a mixed study. Studies in Higher Education, DOI: $10.1080 / 03075079.2020 .1723523$.

Yildız, Z. (2002). The Practising levels of students at different teaching levels for orthography and punctuation rules. Unpublished master's thesis, Suleyman Demirel University, Isparta, Turkey. 